Vol. 16 (2007): 89-102

\title{
Genetic variation of loin and ham quality in Finnish Landrace and Large White pigs
}

\author{
Marja-Liisa Sevón-Aimonen \\ MTT Agrifood Research Finland, Biotechnology and Food Research, FI-31600 Jokioinen, Finland, \\ email: marja-liisa.sevon-aimonen@mtt.fi \\ Markku Honkavaara \\ Finnish Meat Research Institute, PO Box 56, FI-13101 Hämeenlinna, Finland \\ Timo Serenius, Asko Mäki-Tanila \\ MTT Agrifood Research Finland, Biotechnology and Food Research, FI-31600 Jokioinen, Finland
}

Matti Puonti

Faba Breeding, PO Box 40, FI-01401 Vantaa, Finland

\begin{abstract}
Selection potential for meat quality of economically important loin (longissimus) and ham muscles (adductor, semimembranosus, biceps femoris) has been assessed. Ultimate $\mathrm{pH}\left(\mathrm{pH}_{\mathrm{u}}\right.$ ), meat colour (lightness, redness and yellowness), drip loss and two visually scored colour traits were recorded from 483 Finnish Landrace and 494 Finnish Large White station test pigs in a half-sib design. A univariate restricted maximum likelihood procedure was used to estimate variance components. The statistical model contained age at beginning of test, sex and time lapse from slaughter to dissection as fixed effects and slaughter batch, common environment of littermates and additive genetic effect of the animal as random effects. The average $\mathrm{pH}_{\mathrm{u}}$ values in adductor and semispinalis were between 5.6 and 6.1. The $\mathrm{pH}_{\mathrm{u}}$ were on average 5.4 and 5.5 in longissimus and semimembranosus respectively, with the latter two being lower than optimum values of 5.6 to 5.9. Lightness for semimembranosus turned to be clearly lighter (62) than for other muscles. Lightness for longissimus (56) was slightly lighter than optimum (from 48 to 54 ). The heritability varied from zero to 0.45 for $\mathrm{pH}_{\mathrm{u}}$, from 0.02 to 0.34 for lightness, from 0.17 to 0.56 for redness, from zero to 0.28 for yellowness and from 0.05 to 0.16 for drip loss. Heritability for redness values was considerably higher than heritability for other meat quality traits. The heritability of quality traits spoke for possibilities for genetic improvement of meat quality. Genetic correlations between quality traits $\left(\mathrm{pH}_{\mathrm{u}}\right.$ and lightness) and average daily gain varied strongly among breeds and muscles. Genetic correlations between meat- $\%$ and $\mathrm{pH}_{\mathrm{u}}$ were in most cases high and unfavourable ( $\mathrm{rg}$ from -0.36 to -0.68 except in longissimus, where it was 0.11 ). Genetic correlations between meat- $\%$ and lightness were unfavourable in Finnish Large White (from 0.47 to 0.92 ) but in Finnish Landrace estimates varied among muscles (from -0.40 to 0.47 ). Due to these results, the ham quality ( $\mathrm{pH}_{\mathrm{u}}$ and lightness for semimembranosus) was included in the selection criteria for pork quality in the Finnish pig improvement programme.
\end{abstract}

Key-words: heritability, pork, meat quality, ham, loins 
Sevón-Aimonen M.-L. et al. Genetic variation of loin and ham quality

\section{Introduction}

Pork quality such as colour affects acceptability of retail cuts (Bredahl et al. 1998). Especially technological meat quality traits (such as drip loss and water binding capacity) have become important due to increased consumption of whole meat products. Also efforts to decrease the use of additives such as salt $(\mathrm{NaCl})$ and phosphates in meat products increase the demands for improvement of technological meat quality (Puolanne et al. 2001).

The selection for high growth rate and low back fat thickness or muscularity in pigs has affected meat quality (Grandhi and Cliplef 1997, Knapp et al. 1997, Sonesson et al. 1998). A comparison of the modern intensively selected pig and the unselected line representing the pig population existing 20 years ago (Oksbjerg et al. 2000, Tribout et al. 2003), and selection experiments (Sonesson et al. 1998, Cameron et al. 1999) have shown some deterioration in water holding capacity, meat colour, tenderness and $\mathrm{pH}$. Meat quality is a breeding goal in pig improvement programmes in many countries (Schwörer et al. 1994, Hovenier et al. 1995).

In Finland, meat quality of loin has been one of the breeding objectives since 1983 and of ham since 2000. Measuring the technological quality as drip loss and water holding capacity is labour demanding. Therefore the selection programmes are utilising correlated traits: meat colour and $\mathrm{pH}$ either $45 \mathrm{~min}\left(\mathrm{pH}_{1}\right)$ or $24 \mathrm{~h}\left(\mathrm{pH}_{\mathrm{u}}\right)$ post mortem (Joo et al. 1995). The $\mathrm{pH}_{\mathrm{u}}$ and colour are optimum traits. Colour heterogeneity among muscles is also undesirable and, for ham it is assessed by visual standards (National pork producer council 1999) or by a bi-colour index (Tribout et al. 2003).

The Commission Internationale de l'Éclairage (CIE) $\mathrm{L}^{*} \mathrm{a} * \mathrm{~b} *$ standard (CIE 1971), measuring lightness $\left(\mathrm{L}^{*}\right)$, redness $\left(\mathrm{a}^{*}\right)$ and yellowness $\left(\mathrm{b}^{*}\right)$, has been routinely used since 1992 in Finish pig breeding scheme. At present, the main purpose of the meat quality selection in Finland is to increase meat ultimate $\mathrm{pH}\left(\mathrm{pH}_{\mathrm{u}}\right)$ and decrease lightness.

Earlier the main emphasis was on loin quality. Meat industry has in general worried that selection for growth rate and meat percentage may im- pair ham quality (Honkavaara and Puonti 2002). Although the correlation of measurements on the same quality trait in different muscles is positive (Hovenier et al. 1992), it is possible that the quality of ham has deteriorated, when the selection has based solely on loin.

The main objective of this study was to examine the quality $\left(\mathrm{pH}_{\mathrm{u}}\right.$, colour, drip loss, and two subjective scoring) of economically important loin and ham muscles, and to estimate heritabilities for these quality traits in Finnish Landrace and Finnish Large White pigs.

\section{Material and methods}

\section{Populations studied}

Data was obtained from six test stations used in the breeding programme coordinated by the Finnish Animal Breeding Association. There were altogether 977 pigs, including 483 Finnish Landrace (LR) and 494 Finnish Large White (LW) pigs slaughtered between 23 June and 8 September in 1999. The pedigrees were traced back to 1994 . Both breeds have been free of the halothane gene since 1988 (Puonti and Schulman 1988). The data consisted of both half-sibs and full-sibs reared in a test station. Sires had on average five full-sib groups with different dams (Table 1). A full-sib group included three pigs, either females or castrates or both. The test period commenced at $30 \mathrm{~kg}$ and ended at about $100 \mathrm{~kg}$ body weight. The test procedure is more precisely described by Serenius et al. (2001). The pigs were reared in batches of 30 to 100 animals (rearing batch).

\section{Handling and slaughtering}

The six test stations, which belong to Finnish national pig breeding scheme were located in different parts of Finland and the pigs were slaughtered at three different slaughterhouses. The pigs were fed 


\section{AGRICULTURAL AND FOOD SCIENCE}

\section{Vol. 16 (2007): 89-102}

Table 1. Structure and size of data.

\begin{tabular}{lcc}
\hline & $\begin{array}{c}\text { Finnish } \\
\text { Landrace }\end{array}$ & $\begin{array}{l}\text { Finnish } \\
\text { Large White }\end{array}$ \\
\hline Animals with records & 483 & 494 \\
-Half-sib groups & 80 & 76 \\
-Full-sib groups & 175 & 206 \\
Pedigree animals & 1124 & 1080 \\
without records & & \\
Rearing batches & 16 & 17 \\
Slaughter batches & 20 & 20 \\
\hline
\end{tabular}

last time in previous evening before sending to slaughterhouse. They were loaded without electric prod and transported by normal slaughter transportation. The animals were not mixed with animals from other farms during transportation or in lairage. There were some differences in transportation length and time from last feeding to transportation between slaughter batches. The transportation time was about three hours. The pigs were allowed to rest for some 2 to 6 hours before slaughtering. They were stunned with carbon dioxide. Because there was no possibility to standardize handling during transportation and slaughter, slaughter batch was included into the statistical model. The slaughter batch contained the pigs, which were slaughtered at same day and same slaughterhouse. On the following day, the left side of the carcasses was transported to Finnish Meat Research Institute for the measurement of carcass and meat quality. The time from slaughter to dissection was normally from 1 to 3 days but at the maximum it was 7 days. Until dissection, the carcasses were stored at $4{ }^{\circ} \mathrm{C}$.

\section{Traits measured}

The traits recorded from the tested animals were meat percentage (meat- $\%$ ) and average daily gain (ADG) between $30 \mathrm{~kg}$ and $100 \mathrm{~kg}$. Meat- $\%$ was calculated by following formula:

$$
a+b_{1} x_{1}+b_{2} x_{2}+b_{3} x_{3}
$$

where $\mathrm{a}=-8.34, \mathrm{~b}_{1}=1.186, \mathrm{~b}_{2}=0.918, \mathrm{~b}_{3}=-0.035$ and $\mathrm{x}_{1}=100 \times$ (red meat $\mathrm{kg}+$ bone $\mathrm{kg}$ in back and ham) / carcass without head $\mathrm{kg}, \mathrm{x}_{2}=$ shoulder and anterior back cut $\mathrm{kg} /$ carcass without head $\mathrm{kg}$ and $\mathrm{x}_{3}$ is fat thickness at shoulder. Average daily gain was calculated by following formula:

$\mathrm{ADG}=(($ carcass weight $\mathrm{kg} / 0.74)-30 \mathrm{~kg}) /$

(age at slaughter - age at $30 \mathrm{~kg}$ live weight) days.

The muscles studied were semispinalis capitis in neck (central area), longissimus (at last rib) and ham muscles adductor, semimembranosus (lateral area) and biceps femoris. For semispinalis capitis only $\mathrm{pH}_{u}$ and for biceps femoris only colour was measured. For all other muscles both $\mathrm{pH}_{\mathrm{u}}$ and colour were measured. Of the studied muscles, the semispinalis capitis and adductor were considered as dark muscles and other ones as light muscles. The measured traits are presented in Table 2 .

Colour was measured using Minolta CR 300 colour meter and CIE L*a*b* standard (CIE 1971, Warriss 1996) after 5 minutes from cutting fresh surface of a muscle. The 5 minutes period was used because this was the practice in the station test procedure (Kangasniemi 1993). Most of the changes of colour occur during the first 5-10 minutes (Brewer et al. 2001). The device was calibrated with D65 light source and a white plate. $L^{*}$ value is a measure for lightness (black-white axis, higher values means lighter colour), $a^{*}$ value for redness (red-green spectrum, higher value means redder colour) and $b^{*}$ value for yellowness (yellow-blue spectrum, higher values means more yellow colour). The $\mathrm{pH}_{\mathrm{u}}$ (ultimate $\mathrm{pH}$ ) was measured using Knick 752 pH-meter and Ingold 406-elektrod.

To record drip loss, a $200 \mathrm{~g}$ piece at the lateral part of semimembranosus was cut and put into a plastic bag and stored at $4^{\circ} \mathrm{C}$ for seven days (modification from the method by Honikel 1998). The seven days guaranteed the same storing period as the weekday of slaughter varied. Drip loss was calculated as a percentage of the weight lost of meat piece during the storing.

The ham was visually scored. First, the colour uniformity was scored using a scale from 1 to 5 . A score 1 denotes heterogeneous colour containing 


\section{AGRICULTURAL AND FOOD SCIENCE}

Sevón-Aimonen M.-L. et al. Genetic variation of loin and ham quality

Table 2. Means, minimum (min), maximum (max) and standard deviations (SD) of studied traits in Finnish Landrace and Finnish Large White pigs.

\begin{tabular}{|c|c|c|c|c|c|c|c|c|}
\hline & \multicolumn{4}{|c|}{ Finnish Landrace } & \multicolumn{4}{|c|}{ Finnish Large White } \\
\hline & mean & SD & $\min$ & $\max$ & mean & SD & $\min$ & $\max$ \\
\hline Age at $30 \mathrm{~kg}$ weight, $\mathrm{d}$ & 81.3 & 6.61 & 64.9 & 104.5 & 85.3 & 6.30 & 71.2 & 102.9 \\
\hline Age at slaughter, $\mathrm{d}$ & 151.6 & 8.53 & 126.2 & 180.4 & 156.9 & 8.23 & 138.0 & 200.3 \\
\hline Live weight at slaughter, $\mathrm{kg}$ & 101.5 & 5.75 & 83.3 & 113.3 & 100.2 & 6.13 & 79.0 & 113.7 \\
\hline Average daily gain, $\mathrm{g} / \mathrm{d}$ & 1027 & 99.1 & 634 & 1430 & 991 & 100.5 & 624 & 1418 \\
\hline Meat percentage, $\%$ & 63.3 & 2.04 & 55.8 & 71.2 & 63.7 & 1.98 & 55.6 & 70.1 \\
\hline \multicolumn{9}{|l|}{ Ultimate $\mathrm{pH}$} \\
\hline Semimembranosus & 5.39 & 0.11 & 5.15 & 6.03 & 5.44 & 0.10 & 5.26 & 6.02 \\
\hline Adductor & 5.62 & 0.19 & 5.36 & 6.72 & 5.67 & 0.19 & 5.35 & 6.43 \\
\hline Longissimus & 5.39 & 0.15 & 5.09 & 6.16 & 5.47 & 0.14 & 5.03 & 6.26 \\
\hline Semispinalis capitis & 6.10 & 0.29 & 5.57 & 6.92 & 6.14 & 0.27 & 5.56 & 6.85 \\
\hline \multicolumn{9}{|l|}{ Lightness } \\
\hline Semimembranosus & 61.7 & 4.1 & 46.6 & 79.7 & 61.9 & 4.8 & 47.2 & 76.1 \\
\hline Adductor & 48.0 & 3.7 & 34.9 & 58.6 & 47.8 & 4.1 & 37.4 & 60.0 \\
\hline Biceps femoris & 56.6 & 3.8 & 43.0 & 66.4 & 58.4 & 3.3 & 46.8 & 68.6 \\
\hline Longissimus & 56.5 & 3.9 & 41.5 & 67.0 & 55.6 & 3.9 & 42.7 & 65.6 \\
\hline \multicolumn{9}{|l|}{ Redness } \\
\hline Semimembranosus & 6.3 & 1.6 & 2.6 & 12.3 & 5.8 & 1.6 & 1.5 & 14.4 \\
\hline Adductor & 14.7 & 2.3 & 7.8 & 24.3 & 12.9 & 2.1 & 6.0 & 20.2 \\
\hline Biceps femoris & 7.7 & 2.4 & 2.7 & 28.3 & 6.7 & 1.9 & 2.7 & 15.5 \\
\hline Longissimus & 6.9 & 1.3 & 3.6 & 11.7 & 6.1 & 1.2 & 2.4 & 10.0 \\
\hline \multicolumn{9}{|l|}{ Yellowness } \\
\hline Semimembranosus & 5.3 & 1.5 & 1.7 & 15.3 & 5.0 & 1.4 & 1.2 & 9.7 \\
\hline Adductor & 6.4 & 1.4 & 2.2 & 12.1 & 5.6 & 1.6 & 2.0 & 12.7 \\
\hline Biceps femoris & 4.6 & 1.3 & 1.0 & 13.0 & 4.4 & 1.2 & 1.0 & 8.1 \\
\hline Longissimus & 4.2 & 1.2 & 0.6 & 8.9 & 3.6 & 1.0 & 0.7 & 6.7 \\
\hline Drip loss, $\%$ & 6.1 & 1.8 & 1.1 & 12.3 & 5.7 & 1.8 & 0.9 & 12.2 \\
\hline Uniformity of ham, points & 3.2 & 0.9 & 1.0 & 5.0 & 3.0 & 0.8 & 1.0 & 5.0 \\
\hline Light part of topside, $\%$ & 20.7 & 14.0 & 5 & 80 & 22.1 & 14.5 & 5 & 80 \\
\hline
\end{tabular}

\section{Statistical analysis}

both very dark purple (DFD meat) and light parts (PSE) (undesirable appearance), 2 denotes clear differences in colour between muscles, 3 denotes some differences and 4 only very few differences. A score 5 stands for very uniform light red colour (good appearance). Secondly, because of the lateral area of semimembranosus was exhibiting much variation in colour, the proportion of light part (very pale part of topside) was appraised as percentage of whole topside (adductor and semimembranosus together).
Variance components were estimated using an animal model and restricted maximum likelihood method. The analyses were carried out using the DMU package (Jensen and Madsen 2000) and average information algorithm (Johnson and Thompson 1995).

The following statistical model was used for the quality traits:

$\mathrm{y}_{\mathrm{ijklmno}}=\mathrm{s}_{\mathrm{i}}+\mathrm{age}_{\mathrm{j}}+\mathrm{t}_{\mathrm{k}}+\mathrm{d}_{1}+\mathrm{l}_{\mathrm{m}}+\mathrm{a}_{\mathrm{n}}+\mathrm{e}_{\mathrm{ijklmno}}$, 


\section{AGRICULTURAL AND FOOD SCIENCE}

Vol. 16 (2007): 89-102

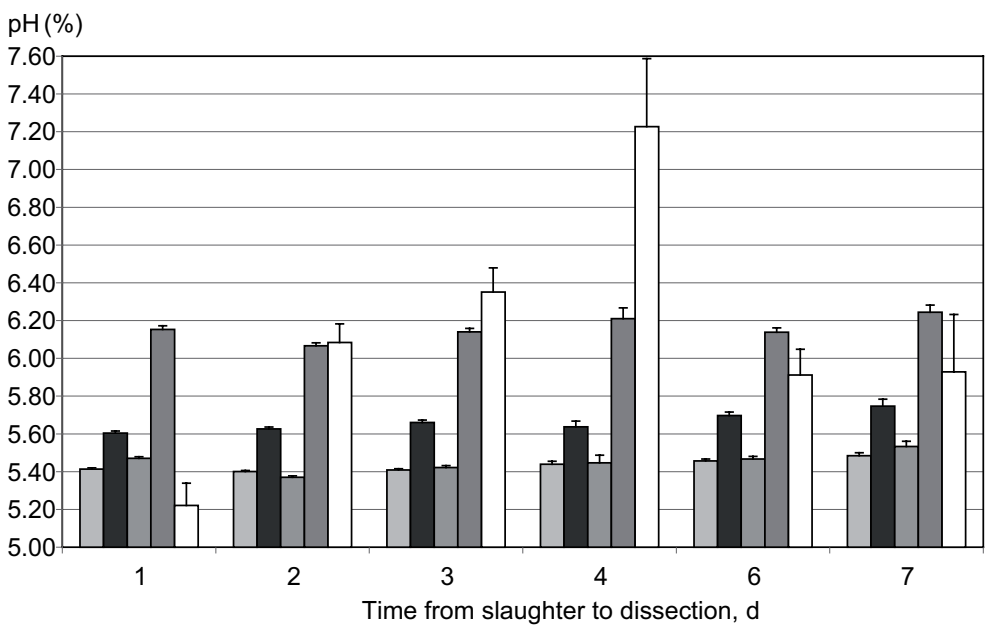

口Semimembranosus $\square$ Adductor $\square$ Longissimus aSemispinalis capitis aDrip loss (\%)

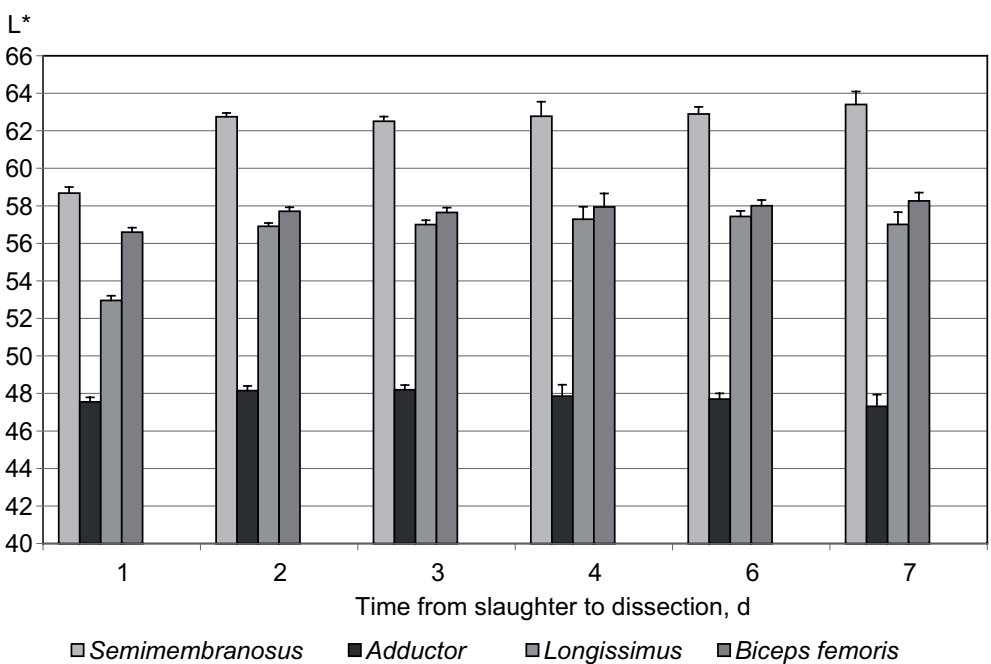

Fig. 1. Means and standard errors of estimates of $\mathrm{pH}_{\mathrm{u}}$ (semimembranosus, adductor, longissimus and semispinalis capitis) and drip loss \% (semimembranosus) from 1 to 7 days after slaughter.

Fig. 2. Means and standard errors of estimates of $\mathrm{L}^{*}$ (semimembranosus, adductor, biceps femoris and longissimus) from 1 to 7 days after slaughter.

where $\mathrm{y}_{\mathrm{ijk} \text { mno }}$ is an observation for different meat quality traits, $s_{i}$ is the fixed effect of sex (female and castrate), age ${ }_{j}$ is fixed effect of age of an animal at the beginning of a test period $(j=1$ to 3 with $j$ representing age under $72 \mathrm{~d}, 2$ from 73 to $78 \mathrm{~d}$ and 3 over $78 \mathrm{~d}$ ), tk is fixed effect of time from slaughter to dissection ( $\mathrm{k}=1$ to $7 \mathrm{~d}), \mathrm{dl}$ is random effect of slaughter batch (common environment of animals slaughtered at same slaughter house and day), $1_{\mathrm{m}}$ is random effect of litter (common environment of litter mates), an additive genetic effect of an animal, and $\mathrm{e}_{\mathrm{ijklmno}}$ residual effect.
The following model was applied for average daily gain and meat percentage:

$\mathrm{y}_{\mathrm{ijklmno}}=\mathrm{s}_{\mathrm{i}}+$ age $_{\mathrm{j}}+\mathrm{p}_{\mathrm{k}}+\mathrm{l}_{\mathrm{m}}+\mathrm{a}_{\mathrm{n}}+\mathrm{e}_{\mathrm{ijklmno}}$,

Other effects were same as described above, but instead of a random slaughter batch effect, the rearing batch $p_{k}(k=1$ to 20$)$ is included in to the model as a fixed effect. When genetic and phenotypic correlations between production and meat quality traits were analysed, simplified model without litter effect was used. 


\section{AGRICULTURAL AND FOOD SCIENCE}

\section{Sevón-Aimonen M.-L. et al. Genetic variation of loin and ham quality}

Regression analysis (SAS 2000) was used to find the best predictors of drip loss among different combinations of ham and loin $\mathrm{pH}_{\mathrm{u}}$ and colour scores.

\section{Results}

Differences in $\mathrm{pH}_{\mathrm{u}}$ and colour between dark (semispinalis capitis and adductor) and light muscles (semimembranosus, longissimus and biceps femoris) were large (Table 2). Usually muscles with high $\mathrm{pH}_{\mathrm{u}}$ had low L* and $\mathrm{b}^{*}$ values. Although the $\mathrm{pH}_{\mathrm{u}}$ values were equal in semimembranosus and longissimus, $\mathrm{L}^{*}$ value was lower in longissimus than in semimembranosus. $\mathrm{L}^{*}$ in semimembranosus was clearly higher than $\mathrm{L}^{*}$ in all other muscles studied.

Variation of $\mathrm{pH}_{\mathrm{u}}$ was higher in dark than in light muscles, being highest in semispinalis capitis. Similarly, also variation of $\mathrm{a}^{*}$ and $\mathrm{b}^{*}$ values tended to be higher in dark muscles. Otherwise, the variation of $\mathrm{L}^{*}$ value was highest in the semimembranosus.

\section{Breed}

Finnish Landrace pigs had a higher average daily gain (Table 2). The meat percentage was higher in LW pigs, but the difference between breeds was not large.

The difference in $\mathrm{pH}_{\mathrm{u}}$ value between the breeds was small. Minolta $a^{*}$ and $b^{*}$ values of all the muscles were, in general, slightly higher in LR. The drip loss was 0.6 percentage units higher in LR, which would be expected from the slightly lower $\mathrm{pH}_{\mathrm{u}}$ values. In subjective evaluation the proportion of light part in semimembranosus was lower in LR and the colour of ham was slightly more uniform than in LW pigs. Overall, the differences between muscles were clearly larger than differences between breeds. Standard deviations of meat quality traits were quite similar in both breeds.

\section{The effect of time laps from slaughter to dissection}

The time laps from slaughter to dissection (varied from 1 to 7 days) had a very strong effect on the meat quality traits (Figs 1 and 2). Most of the deterioration happened between the first and second day after slaughter. Lightness value of semimembranosus and longissimus increased four units and $\mathrm{pH}_{\mathrm{u}}$ dropped 0.1 units between the first and second day. After that $\mathrm{L}^{*}$ values stayed constant but $\mathrm{pH}_{\mathrm{u}}$ increased slightly. There were differences between muscles so that in all the light muscles and in semispinalis capitis, $\mathrm{pH}_{\mathrm{u}}$ first declined and then started to increase. In contrast, in adductor the colour stayed almost stable and $\mathrm{pH}_{\mathrm{u}}$ started to increase even in the first day after slaughter. Also drip loss increased along with the increasing time from slaughter, the values being elevated from 5.2\% on the first day to the maximum value of $7.2 \%$ on the fourth day and then it declined near to $5 \%$.

\section{Heritabilities}

Heritability was moderate or high for meat- $\%$ and for average daily gain in LR but the values in LW were markedly lower. On the other hand, the heritability of meat $\mathrm{pH}_{\mathrm{u}}$ and colour was generally clearly lower in LR than in LW (Table 3). The heritability of L* and $b^{*}$ was low or moderate and similar in both the light and dark muscles. The heritability of $\mathrm{pH}_{\mathrm{u}}, \mathrm{L}^{*}$ and $b^{*}$ in different muscles varied from 0.0 to 0.13 in LR and from 0.0 to $0.45 \mathrm{in} \mathrm{LW.} \mathrm{The} \mathrm{heritability} \mathrm{of}$ $\mathrm{a}^{*}$ in different muscles ranged from 0.17 to 0.38 in LR and from 0.18 to 0.56 in LW being clearly higher that of the other meat quality traits. The heritability for drip loss was 0.16 in LR and lower in LW. When analysing the heritability for subjectively scored traits the convergence criterion was not reached.

\section{Slaughter batch}

Proportion of variation due to common slaughter batch (d2) in the meat quality traits was on average 0.06 in LR and 0.09 in LW and varied from 0.00 to 
0.20 with inconsistency between the breeds in the traits (Table 3). In most of the muscles, $\mathrm{d} 2 \mathrm{of} \mathrm{pH}_{\mathrm{u}}$ and $\mathrm{L}^{*}$ was in LR almost two times higher. In both breeds, the slaughter batch had a clear effect on drip loss (d2 $=0.16$ in LR and 0.13 in LW) and less on $\mathrm{a}^{*}$ and $\mathrm{b}^{*}$ values of biceps femoris and $\mathrm{a}^{*}$ of longissimus, whilst the effect was weak on $\mathrm{pH}_{\mathrm{u}}$ of dark muscles, and stronger on $\mathrm{L}^{*}$ and $\mathrm{a}^{*}$ values of biceps femoris and longissimus than on other muscles.

\section{Litter}

The proportion of variation due to common environment of littermates (c2) was 0.0 in ADG in both breeds and negligible in meat- $\%$ in LR (Table 3). The $\mathrm{c} 2$ of $\mathrm{pH}_{\mathrm{u}}$ in different muscles was higher and varied from 0.05 to 0.19 in LR and from 0.01 to 0.20 in LW. For the colour traits, c2 was lower. Moreover, c2 was quite high in drip loss of LR, with the values being over 0.15 .

\section{Correlations}

Genetic and phenotypic correlations between meat quality traits and ADG and meat- $\%$ are presented in Table 4. Genetic correlations between $\mathrm{ADG}$ and $\mathrm{pH}_{\mathrm{u}}$ varied from -0.11 to 0.35 in the different muscles and breeds. Genetic correlations between ADG and $L^{*}$ varied between -0.56 and 0.52 . Phenotypic correlations between $\mathrm{ADG}$ and $\mathrm{pH}_{\mathrm{u}}$ or $\mathrm{L}^{*}$ were close to zero. Genetic correlations between meat- $\%$ and $\mathrm{pH}_{u}$ were unfavourable in all muscles in both breeds (from -0.36 to -0.68 ) except longissimus in LR (0.11). Genetic correlations between meat-\% and $\mathrm{L}^{*}$ were highly positive in LW (from 0.47 to 0.92 ) but varied widely in LR (from -0.40 to 0.47 ). Genetic correlations between ADG and drip loss were moderately positive and similar in both breeds $(0.22$ and 0.39$)$. Correlations between meat- $\%$ and drip loss were negative and low in LR $(-0.06)$ but unexpectedly very highly negative in LW $(-0.41)$. Standard errors of correlations were high.

\section{Predictors for drip loss}

Both linear and quadratic terms of colour traits and $\mathrm{pH}_{\mathrm{u}}$ to predict the drip loss of semimembranosus were studied. The quadratic effects were not significant, neither was the interaction between breed and $\mathrm{pH}_{\mathrm{u}}$ or colour. Of the studied traits, the $\mathrm{pH}_{\mathrm{u}}$ of longissimus and semimembranosus had the largest effect on drip loss. The best single trait to predict drip loss was $\mathrm{pH}_{\mathrm{u}}$ of semimembranosus. Colour or $\mathrm{pH}_{\mathrm{u}}$ of biceps femoris and dark muscles (adductor, semispinalis capitis) were not as good predictors as the same measurements from longissimus and semimembranosus. The best combination was $\mathrm{pH}_{u}$ of longissimus and $\mathrm{L}^{*}$ of semimembranosus $\left(\mathrm{R}^{2}=\right.$ 0.25 ). The best predictors were found to be the same in both breeds.

\section{Discussion}

\section{Meat quality in different muscles}

The studied muscles differed strongly in quality traits. This has also been found in other studies where several muscles were compared (Warner et al. 1993, Lindahl et al. 2001). Lightness values under 58 (optimal value between 48 and 54) (Kauffman et al. 1993, Van Oeckel et al. 1999) and $\mathrm{pH}_{\mathrm{u}}$ between 5.6 and 5.9 (Joo et al. 1995) have been presented as a criterion for good meat quality. Suchlike criterion have not been given for $\mathrm{a}^{*}$ and $\mathrm{b}^{*}$ values.

In this study, the $\mathrm{L}^{*}$ value of longissimus was 56.5 in LR and 56.6 in $\mathrm{LW}$ and $\mathrm{pH}_{\mathrm{u}}$ was 5.39 and 5.47 , respectively. The meat quality of longissimus $\left(\mathrm{L}^{*}\right.$ and $\left.\mathrm{pH}_{\mathrm{u}}\right)$ seems to be at the same level as in the Danish Landrace (Oksbjerg et al. 2000) and in the Swedish Landrace and Swedish Large White (Lindahl et al. 2001). The lightest studied muscle was semimembranosus, in which the $L^{*}$ value 62 was clearly over the desirable level. The high value was partly explained by the measuring point, which was lateral part on topside and at the lightest part of the muscle. In biceps femoris, $\mathrm{L}^{*}$ value was higher than in longissimus, but still within accepted limits. In the 
Sevón-Aimonen M.-L. et al. Genetic variation of loin and ham quality

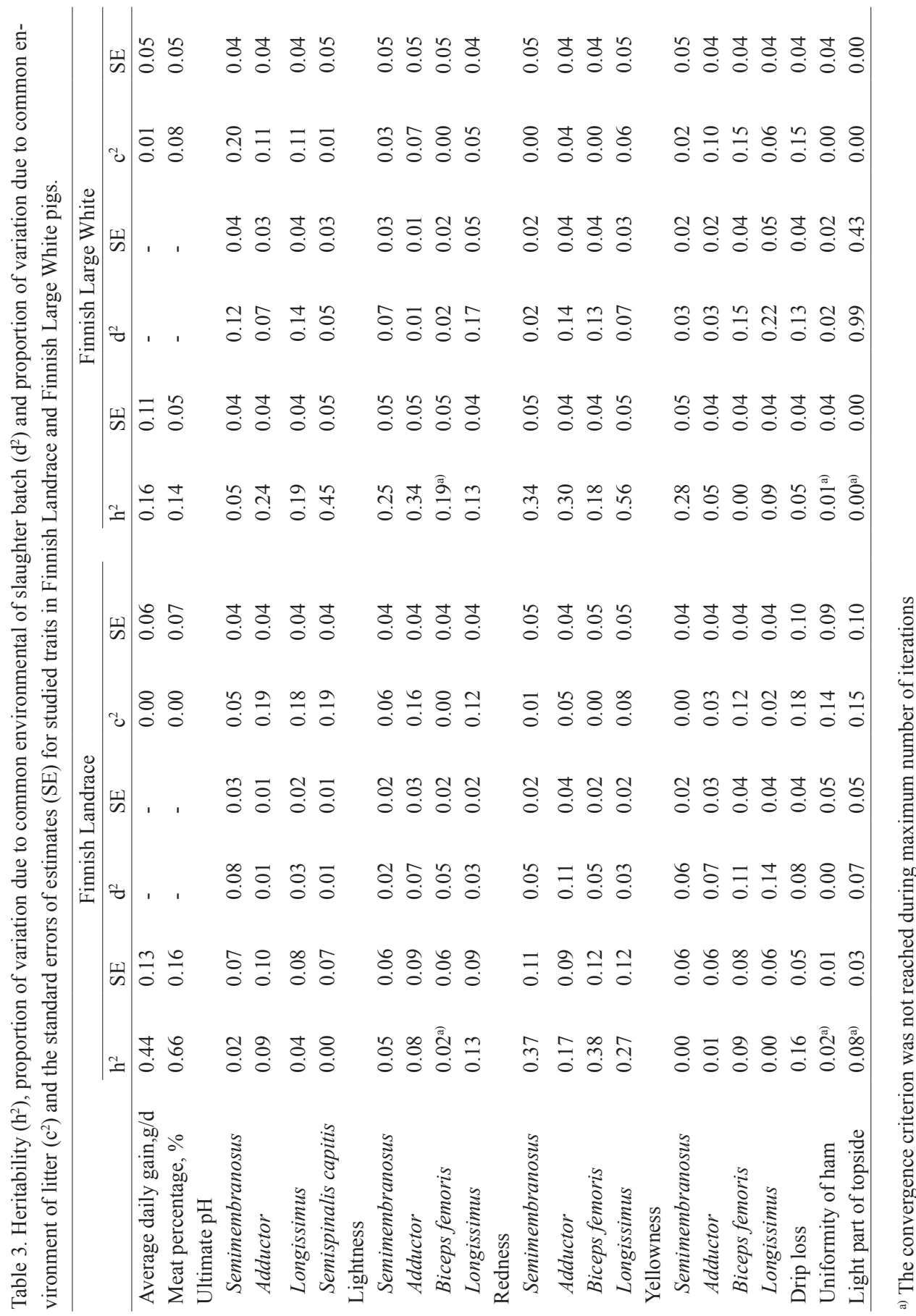


Vol. 16 (2007): 89-102

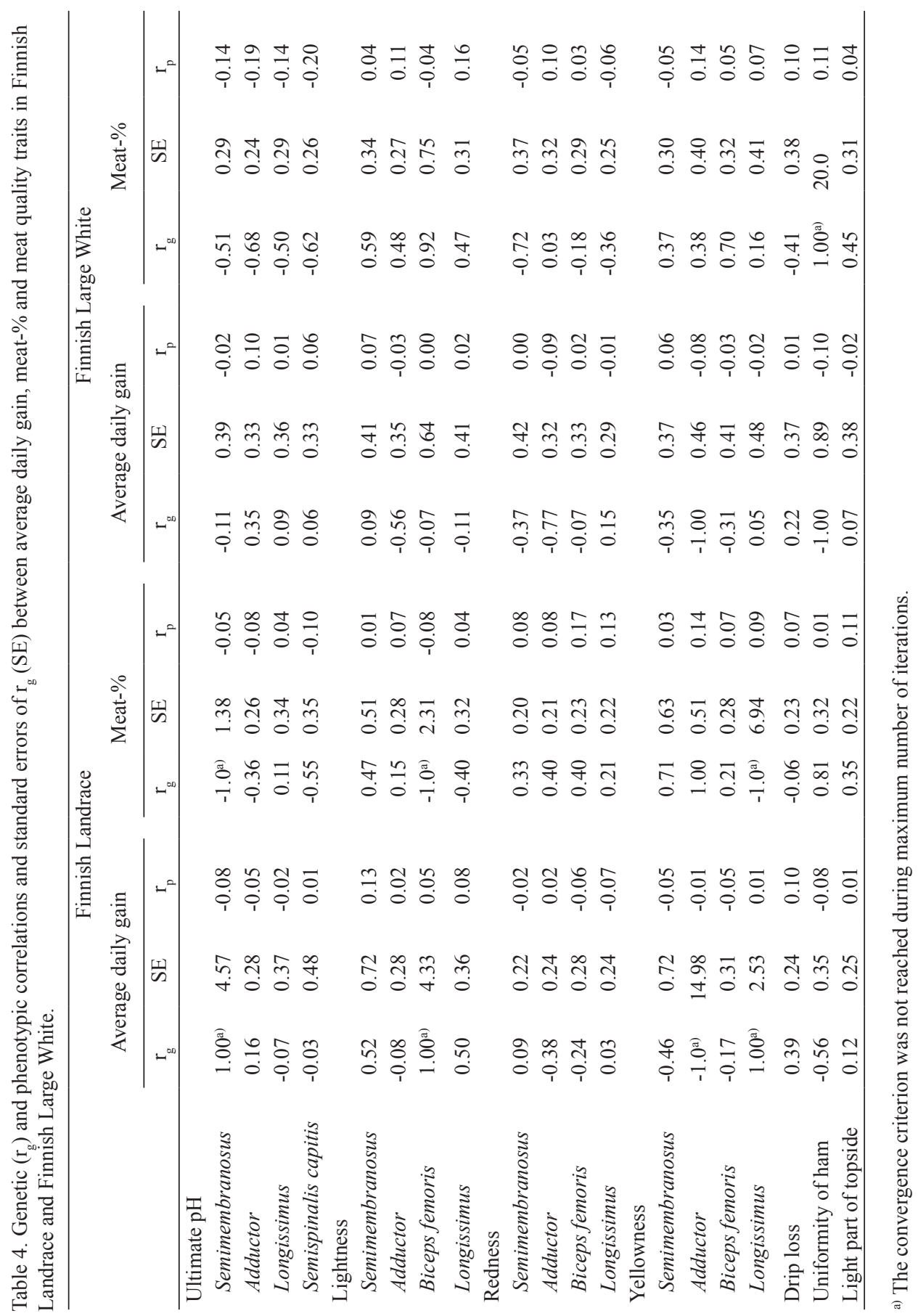




\section{AGRICULTURAL AND FOOD SCIENCE}

\section{Sevón-Aimonen M.-L. et al. Genetic variation of loin and ham quality}

Swedish Landrace and Swedish Large White, the $\mathrm{L}^{*}$ of biceps femoris was lower, indicating darker colour, but it was measured from the inner part of the muscle (Lindahl et al. 2001).

\section{The effect of time laps from slaughter to dissection}

In the current study, $\mathrm{pH}_{\mathrm{u}}$ declined and $\mathrm{L}^{*}$ increased between the first and second day after slaughter (Figs 1 and 2). But when storage time lengthened further, these trends reversed and the $\mathrm{pH}_{\mathrm{u}}$ increased while the $\mathrm{L}^{*}$ decreased. In the literature, $\mathrm{pH}$ has been found to decrease even after 24 hours (Marchiori and Felicio 2003). Lightness has been found to first increase, and then after few days storage, begin to decrease (Lindahl et al. 2006). In this study, the drip loss increased linearly as the time lapse from slaughter to dissection increased from one day to four days and the total time from slaughter to weighing the meat samples accordingly increased from 8 days to 11 days (the meat samples were stored for 7 days). In the literature, drip loss has been found to increase curvilinearly with increasing storage time for at least seven days (Otto et al. 2006). Drip losses measured after various storage times have been found to be highly correlated (Otto et al. 2006). In the current study, the decline of the drip loss after six or seven days time lapse from slaughter to dissection was not expected (Fig. 1) and might be a consequence of evaporation and drip loss in half carcases before cutting samples for drip loss measurement.

\section{Heritabilities}

The heritability of the same meat quality trait was, in general, at same level in different muscles. They differed between the breeds and the estimates were clearly higher in LW than in LR for most of the traits. This may be due to the small data set. However, also in larger data sets differences between breeds have been found. The heritabilities of colour, $\mathrm{pH} 1$ and drip loss were higher in Large White than in Landrace
(Knapp et al. 1997, Andersen and Pedersen 1999). It is possible that there are true genetic differences in heritability between LR and LW.

The low and moderate heritability for the meat quality traits found in this study are in accordance with those reviewed by Hovenier et al. (1993). Occasionally, very high heritability for $\mathrm{L}^{*}$ and $\mathrm{pH}_{\mathrm{u}}$ values have been found even in halothane gene free populations (Sonesson et al. 1998). In our data, heritability for a* value was clearly higher than for the other quality traits. The few previously published heritability estimates for $\mathrm{a}^{*}$ value are consistent with the present study (Andersen and Pedersen 1999).

The traits used in a breeding programme should be easily and cheaply measured from a large number of animals, and the traits must be appropriate to predict the properties of quality expected by consumers and meat processing industry. Lightness value is correlated with both water-holding capacity (Joo et al. 1995) and visual colour (Van Oeckel et al. 1999). Also the amount of pigment is one of the most important factors increasing the darkness and redness of muscle (Lindahl et al. 2001). The phenotypic relationship between redness and water-holding capacity is usually weak (Joo et al. 1995) and the emphasis on redness has been minor in selection. However, heritability of a* was clearly higher than those of the other meat quality traits. It should be possible to increase the accuracy of breeding values by including the $\mathrm{a}^{*}$ into the multitrait evaluation, particularly in selection against lightness of semimembranosus if these traits have genetic correlation as found by Andersen and Pedersen (1999).

\section{Slaughter batch}

In previous studies, usually either litter or slaughter batch effect has been included in the model as a random effect (Knapp et al. 1997, Lindahl et al. 2001). Sometimes the slaughter batch has been considered as a fixed effect (Sonesson et al. 1998). In this study the slaughter batch was considered as random effect because of the number of animals 
varied between days and was generally small.

Slaughter batch effect contains several factors such as transporting, temperature, and handling of animals. The proportion variance due to common environment of slaughter batch (d2) was about 0.07 of the phenotypic variance in the meat quality traits. Especially d2 for drip loss was high in both breeds, establishing the strong effect of slaughter batch on this trait. Andersen and Pedersen (1999) have presented slightly higher estimates. The variation explained by slaughter batch effect ranged between 0.12 and 0.20 for $\mathrm{pH}_{\mathrm{u}}, \mathrm{L}^{*}$ and $\mathrm{b}^{*}$ and between 0.01 and 0.06 for $\mathrm{a}^{*}$. Also Van der Wal et al. (1995) found that the slaughter batch explained 0.15 of phenotypic variation in quality traits. The most important factor contributing to the high slaughter batch effect is the way animals are handled just before slaughter (van der Wal et al. 1997). In this study slaughter was performed in different commercial slaughterhouses. Studying specific factors was not possible but to eliminate the effect of slaughter batch meat quality traits it was included to model.

\section{Litter}

The proportion of variation due to litter (c2) for the meat quality traits was approximately 0.06 across various muscles, and thus, as high as the slaughter batch effect. In previous research, c2 has ranged between 0.03 and 0.14 for $\mathrm{pH} 1$ and colour respectively (Knapp et al. 1997), although lower estimates (from 0.00 to 0.04 ) have been found (Hofer and Schwörer 1995).

\section{Correlations}

In the current study, genetic correlations between ADG and meat quality $\left(\mathrm{pH}_{\mathrm{u}}\right.$ and $\left.\mathrm{L}^{*}\right)$ varied among muscles (Table 4). Genetic correlations between meat- $\%$ and meat quality traits $\left(\mathrm{pH}_{\mathrm{u}}\right.$ and $\left.\mathrm{L}^{*}\right)$ were high and unfavourable in LW but varied in LR. Unexpected negative correlations were found between meat- $\%$ and drip loss in both breeds. In the literature, the correlation between drip loss and meat- $\%$ has been found to be positive (Knapp et al. 1997). The long time lapse from slaughter to dissection and also the long storage time of drip loss samples might be reasons for these unexpected results. Due the negative correlations between quality and production and meat- $\%$, quality traits must be included to the selection programme in order to prevent meat quality deterioration.

\section{Effect of colour and $\mathrm{pH}_{u}$ on drip loss}

The drip loss is more difficult to measure than $\mathrm{pH}_{\mathrm{u}}$ or colour. That's why these easily measurable traits are used to predict drip loss of carcass or valuable muscles. In this data, the $\mathrm{L}^{*}$ value has lower effect on drip loss than $\mathrm{pH}_{\mathrm{u}}$. The $\mathrm{L}^{*}$ value of semimembranosus explained 0.07 and $\mathrm{pH}_{\mathrm{u}}$ of semimembranosus 0.17 of variation in drip loss and together $\left(\mathrm{L}^{*}\right.$ and $\left.\mathrm{pH}_{\mathrm{u}}\right)$ they explained 0.25 of variation of drip loss. Unexpectedly $\mathrm{L}^{*}$ and $\mathrm{pH}_{\mathrm{u}}$ of longissimus predicted the drip loss of semimembranosus as well. Otherwise $\mathrm{L}^{*}$ and $\mathrm{pH}_{\mathrm{u}}$ of other ham muscles were not s good predictors. Schäfer et al. 2002 found the $\mathrm{pH} 1$ to be a better predictor of water holding capacity than $\mathrm{pH}_{\mathrm{u}}$.

\section{Conclusions}

Even though the variation of the same quality traits in different muscles varied, the heritability was of similar magnitude. To determine which muscles should be taken as breeding goal depends on both the economic value of the muscle and on the need for improved quality. The heritability estimates showed that with effective breeding programme it is possible to achieve genetic improvement in meat quality Including highly heritable redness in a breeding program will obviously increase the accuracy of breeding value estimation if it is genetically correlated with $\mathrm{L}^{*}$ and $\mathrm{pH}$. More information of genetic relationship between redness and other 


\section{AGRICULTURAL AND FOOD SCIENCE}

\section{Sevón-Aimonen M.-L. et al. Genetic variation of loin and ham quality}

quality traits is still needed. The semimembranosus turned out to be lighter than desired and therefore the ham quality $\left(\mathrm{pH}_{\mathrm{u}}\right.$ and $\left.\mathrm{L}^{*}\right)$ was included in the selection criteria for pork quality in the Finnish pig improvement programme.

Acknowledgements. The authors would like to thank Faba Breeding for assistance in the project and The Meat Board of the Finnish Food and Drink Industries Federation for financial support.

\section{References}

Andersen, S. \& Pedersen, B. 1999. Genetic parameters for colour traits and $\mathrm{pH}$ and correlation to production traits. In: Wenk, C. et al. (eds.) Quality of meat and fat in pigs as affected by genetics and nutrition. EAAP Publication No. 100. Wageningen Pers 2000. p. 123-126.

Bredahl, L., Grunert, K. G. \& Fertin, C. 1998. Relating consumer perceptions of pork quality to physical product characteristics. Food Quality and Preference 9: 273-281.

Brewer, M.S., Zhu, L.G., Bidner, B., Meisinger D.J. \& McKeith F.K. 2001. Measuring pork color: effects of bloom time, muscle, $\mathrm{pH}$ and relationship to instrumental parameters. Meat Science 57: 169-176.

Cameron, N.D., Nute, G.R., Brown, S.N., Enser, M. \& Wood, J.D.1999. Meat quality of Large White pig genotypes selected for components of efficient lean growth rate. Animal Science 68: 115-127.

CIE 1971. Colorimetry: Official recommendations of the International Commission of Illumination. Publication CIE No. 15. (E-1.3.1) Paris, France. Bureau Central de la CIE: $124 \mathrm{p}$.

Grandhi, R.R. \& Cliplef, R.L. 1997. Effect of selection for lower backfat, and increased levels of dietary amino acids to digestible energy on growth performance, carcass merit and meat quality in boars, gilts, and barrows. Canadian Journal of Animal Science 77: 487-496.

Hofer, A. \& Schwörer, D. 1995. Genetic parameters of production and meat quality traits in station tested Swiss Large White pigs. 46th Annual Meeting of the European Association for Animal Production, Prague 4-7 September, 1995. Commission on Animal Genetics, Session 5: 59 .

Honikel, K.O., 1998. Reference methods for the assessment of physical characteristics of meat. Meat Science 49: 447-457.

Honkavaara, M. \& Puonti, M. 2002. Pork quality and cutting yields of breeding pigs in Finland. In: 48th International Congress of Meat Science and Technology Proceedings Vol. 2: 678-679.

Hovenier, R., Kanis, E., Van Asseldonk, Th. \& Westerink, N.G. 1992. Genetic parameters of pig meat quality traits in a halothane negative population. Livestock Production Science 32: 309-321.
Hovenier, R., Kanis, E., Brascamp, E.W. \& Knapp, P.W. 1995. Including meat quality in breeding programs. In: Smith, C. et al. (eds.) Proceedings, 5th World Congress on Genetics Applied to Livestock Production, University Quelph, Ontario, Canada, 7-12. August 1994. 19: 465-468.

Hovenier, R., Kanis, E. \& Verhoeven, J.A.M. 1993. Repeatability of taste panel tenderness scores and their relationship to objective pig meat quality traits. Journal of Animal Science 71: 2018-2025.

Jensen, J. \& Madsen, P. 2000. A user guide to DMU. A Package for analysing Multivariate Mixed Models. National Institute of Animal Science, Tjele, Denmark. 22 p.

Johnson, D.L. \& Thompson, R. 1995. Restricted maximum likelihood estimation of variance components for univariate animal models using sparse matrix techniques and average information. Journal of Dairy Science 78 : 449-456.

Joo, S.T., Kauffman, R.G., Kim, B.C. \& Kim, C.J. 1995. The relationship between color and water-holding capacity in post rigor porcine longissimus muscle. Journal of Muscle Foods 6: 211-226.

Kangasniemi, R. 1993. Lihan värimittaus kantakokeissa muuttuu. Sika 23:30-31.

Kauffman, R.G., Sybesma, W., Smulders, F.J.M, Eikelenboom, G., Engel, B., van Laack, R.L.J.M., Hoving-Bolink, A.H., Sterrenburg, P., Nordheim, E.V., Walstra, P.\& van der Wal, P.G. 1993. The effectiveness of examining early post-mortem musculature to predict ultimate pork quality. Meat Science 34: 283-300.

Knapp, P., William, A. \& Sölkner, J.1997. Genetic parameters for lean meat content and meat quality traits in different pig breeds. Livestock Production Science 52: 69-73.

Lindahl, G., Enfält, A.-C., Andersen, H.J. and Lundström, K. 2006. Impact of RN genotype and ageing time on colour characteristics of the pork muscles longissimus dorsi and semimembranosus. Meat Science 74: 746-755.

Lindahl, G., Lundström, K. \& Tornberg, E. 2001. Contribution of pigment content, myoglobin forms and internal reflectance to the colour of pork loin and ham from pure breed pigs. Meat Science 59: 141-151.

Marchiori, A. \& Felício, P. 2003. Quality of wild boar meat and commercial pork. Scientia Agricola 60: 1-5.

National Pork Producers Council. 1999. Pork quality standards. Iowa, USA.

Oksbjerg, N., Petersen, J.S., Sørensen, I.L., Henckel, P. Vestergaard, M., Ertbjerg, P., Møller, A. J., Bejerholm, C. \& Støier, S. 2000. Long-term changes in performance and meat quality of Danish Landrace pigs: a study on a current compared with an unimproved genotype. Animal Science 71: 81-92.

Otto, G., Roehe, R., Looft, H., Thoelking, L., Henning, M., Plastowe, G.S. \& Kalm, E. 2006. Drip loss of case-ready meat and of premium cuts and their associations with earlier measured sample drip loss, meat quality and carcass traits in pigs. Meat Science 72: 680-687.

Puolanne, E. J., Ruusunen, M. H. \& Vainionpää, J.I. 2001. Combined effects of $\mathrm{NaCl}$ and raw meat $\mathrm{pH}$ on waterholding in cooked sausage with and without added phosphate. Meat Science 58: 1-7.

Puonti, M. \& Schulman, A.1988. Eradication of halothane gene from Finnish pig population. In: Proceedings VI World Conference on Animal Production. Helsinki: p. 478. 


\section{AGRICULTURAL AND FOOD SCIENCE}

Vol. 16 (2007): 89-102

SAS 2000. SAS OnlineDoc® Version 8.

Schäfer, A., Rosenvold, K., Purslow, P., Andersen, H.J. \& Henckel, P. 2002. Physiological and structural events post mortem of importance for drip loss in pork. Meat Science 61: 355-366.

Schwörer, D., Rebsamen, A. \& Lorenz, D. 1994. Twenty years of selection for meat quality in Swiss pig breeding. Pig News and Information 15: 63-66.

Serenius, T., Sevón-Aimonen, M.-L. \& Mäntysaari, E.A.2001. The genetics of leg weakness in Finnish Large White and Landrace populations. Livestock Production Science 69: 101-111.

Sonesson, A.K., de Greef, K.H. \& Meuwissen, T.H.E. 1998. Genetic parameters and trends of meat quality, carcass composition and performance traits in two selected lines of Large White pigs. Livestock Production Science 57: 23-32.

Tribout, T., Caritez, J.C., Gogue, J., Gruand, J., Bouffaud, M., Le Roy, P. \& Bidanel, J.P. 2003. Estimation of realised genetic trends in French Large White pigs from 1977 to
1998 for production and quality traits using frozen semen. 54th Annual Meeting of the European association for Animal Production, Roma, Italy, August 31th - September 3th, 2003.

Van der Wal, P.G., Engel, B. \& Hulsegge, B. 1997. Causes for variation in pork quality. Meat Science 46: 319-327.

Van der Wal, P.G., de Vries, A.G. \& Eikelenboom, G. 1995. Predictive value of slaughterhouse measuments of ultimate pork quality in seven halothane negative Yorkshire populations. Meat Science 40: 183 - 191.

Van Oeckel, M.J., Warnants, N. \& Boucqué, Ch.V. 1999. Measurement and prediction of pork colour. Meat Science 52: 347 - 354 .

Warner, R.D., Kauffman, R.G. \&Russell, R.I. 1993. Quality attributes of major porcine muscles: a comparison with the Longissimus lumborum. Meat Science 33: 359-372.

Warriss, P. 1996. Instrumental measurement of colour. In: Taylor, S. et al. (eds.) Meat quality and meat packaging. ECCEAMST, Utrecht, The Netherlands. p. 221-232. 


\title{
SELOSTUS
}

\section{Suomalaisten maatiais- ja yorkshirerotuisten sikojen kyljysselän ja kinkun laadun perinnöllinen vaihtelu}

\author{
Marja-Liisa Sevón-Aimonen, Markku Honkavaara, Timo Serenius, Matti Puonti ja Asko Mäki-Tanila \\ MTT Biotekniikka- ja elintarviketutkimus, Lihateollisuuden tutkimuskeskus ja Faba Jalostus
}

Suomessa sikojen tärkeimmät jalostettavat lihasikaominaisuudet ovat olleet kasvunopeus, rehunmuuntosuhde, liha-\% ja kyljysselästä mitattu punaisen lihan laatu (loppu-pH ja väri). Punaisen lihan laatu yleensä huonontuu muiden valittujen ominaisuuksien parantuessa, ja niin sen osalta tavoitteena onkin ollut pitää laatu ennallaan. Kinkun laatua ei sen sijaan oltu mitattu rutiininomaisesti, ja lihateollisuus epäili kinkun laadun heikenneen. Tämän tutkimuksen tarkoitus oli selvittää lihan laatu taloudellisesti tärkeissä kinkun ja kyljysselän lihaksissa sekä laskea laatumittojen perinnölliset tunnusluvut. Tulosten perusteella arvioitiin laatuominaisuuksien kehittämistarve ja mahdollisuudet jalostusvalintaan.

Tutkimusta varten kerättiin kantakoeleikkuun yhteydessä normaalia tarkemmat lihanlaatutiedot 483 maatiais- ja 494 yorkshiresiasta, ja näihin liitettiin sukulaisuustiedot. Ominaisuudet olivat lihan väri (vaaleus, punaisuus ja keltaisuus) sekä $\mathrm{pH}$ tummista (semispinalis capitis, adductor) ja vaaleista (longissimus, biceps femoris, semimembranosus) kyljysselän ja kinkun lihaksista. Lisäksi mitattiin valuma sisäpaistin vaaleasta reunasta otetusta näytteestä, pisteytettiin kinkun tasavärisyys ja arvioitiin hyvin vaalean lihan osuus sisäpaistissa.

Aineisto analysoitiin DMU-ohjelmistolla. Laatuominaisuuksien tilastollisessa mallissa oli kiinteinä tekijöinä sukupuoli, ikä kokeen alussa ja viive teurastuksesta leikkuuseen sekä satunnaisina tekijöinä eläimen additiivinen geneettinen vaikutus, pahnue, teurastuserä ja satunnainen jäännöstermi. Kasvunopeus ja liha-\% -mallissa kasvatuserä oli kiinteänä tekijänä teurastuserän sijaan ja viive oli jätetty pois. Geneettiset korrelaatiot laskettiin yksinkertaistetulla mallilla, josta pahnuetekijä oli jätetty pois.

Lihan väri vaihteli eri lihaksissa. Samoin eri yksilöiden lihan vaaleus vaihteli. Sen sijaan rotujen välillä ei havaittu eroja tutkituissa ominaisuuksissa, joskin maatiaisen lihan väri oli hieman vaaleampaa. Toivottava $\mathrm{pH}$ on 5,6 ja 5,9 välillä. Vaaleuden arvo tulisi olla kirjallisuuden perusteella alle 58 ja mieluimmin 48 ja 54 välillä. Kyljyksen väri oli hyväksyttävä, eli sen keskiarvo oli 56. Tulosten perusteella kinkun suurista lihaksista sisäpaisti (vaaleusarvo 62) oli toivottua vaaleampaa. Samoin vaaleiden lihasten $\mathrm{pH}$ oli matala vaihdellen 5,39 ja 5,47 välillä lihaksen ja rodun mukaan. Vedensidontakyvyltään liha, jonka $\mathrm{pH}$ on matala, on huonompi kuin normaali liha. Kuitenkin yli kuuden oleva loppu-pH voi heikentää lihan säilyvyyttä ja olla merkki eläimen rasituksesta ennen teurastusta.

Lihan laatuominaisuuksien periytymisasteet olivat punaisuutta lukuun ottamatta matalia tai korkeintaan keskinkertaisia. Vaaleuden ja $\mathrm{pH}: \mathrm{n}$ periytymisasteet olivat maatiaisella nollan ja 0,13 välillä ja yorkshirella hieman korkeammat vaihdellen nollasta 0,45:een. Punaisuuden periytymisaste vaihteli eri lihasten välillä 0,17 :sta 0,56 :een. Valuman periytymisaste oli maatiaisella 0,16 ja yorkshirella 0,05 . Periytymisasteet osoittavat, että laatua on mahdollista parantaa valinnalla. Lihan laatuominaisuudet heikkenivät lihakkuuden noustessa, minkä vuoksi lihan laatu on otettava huomioon kasvunopeutta ja lihakkuutta valitessa. Tulosten perusteella sisäpaistista mitattu kinkun laatu sisällytettiin sikojen kantakoeindeksiin vuonna 2000. Lisämittauksia tarvitaan ominaisuuksien välisten tarkkojen geneettisten korrelaatioiden estimoimiseksi. 